\title{
Effective Problem Based Learning Presented in a Blended System: One Step toward Adaptive Learning
}

\author{
Ludfi Djajanto', Siti Rohani2 ${ }^{*}$ \\ ${ }^{1,2}$ State Polytechnic of Malang, Indonesia
}

\begin{abstract}
.
In the era of industrial revolution 4.0, the use of technology and the internet was almost implemented in all fields including education, especially in the learning process. The use of information technology in learning becomes a necessity because it facilitates students and lecturers in carrying out the learning process. Furthermore, problem-based learning sourced from authentic problems are effective and motivating. This study aims to explore the effective implementation of a problem-based learning implemented in a blended system, as a teaching and learning strategy toward adaptive learning method. This experimental research was followed up by identification of students' responses toward the implementation of the strategy. Respondents were 160 students taking a marketing management course; samples were selected through purposive sampling technique. Findings show that there were significant differences between control and experiment groups, confirming the higher significant progress of students learning through problem-based presented in a blended learning system than of students learning through conventional strategy. Nearly all respondents agreed that the problem-based learning presented in the blended system was interesting, motivating and assisting to gain the targeted learning outcomes. This strategy was also one step toward the implementation of adaptive learning method that put individualized learning in a computerized system.
\end{abstract}

Keywords: Problem Based; Blended System; Adaptive Learning

\section{Introduction}

Currently, the development of technology and science is related to the industrial revolution 4.0 , one of which is shown by the use of technology and the internet in almost all fields including education. This is because technology and the internet make it easier for people to do work and activities of daily life. The use of technology that combines the physical and digital worlds will fundamentally change the pattern of human life and interaction (Tjandrawinata, 2016). Besides, by entering the era of the industrial revolution 4.0, there will be a merger between digital and physical domains based on Cyber-Physical Systems (Pannen, 2018). In the world of education, technological developments and the increasing number of people using the internet will directly affect the need to improve the quality of learning. In facing this industrial era 4.0, it is important to make fundamental changes in the education process so that later college graduates can compete in the world of work. The development of the industrial revolution 4.0 has made it easier for humans to carry out their work activities 


\section{$3^{\text {rd }}$ International conference on Advanced Research in Education, Teaching \& Learning}

because most $(75 \%)$ of all current activities already use technology and the internet, including in learning (Sadikin \& Hakim, 2019).

The use of technology in learning is currently needed such as gadgets, smartphones, and androids can be used as media that can make it easier for students to learn independently in mastering a concept (Warsita, 2008). Besides, the use of information technology in carrying out learning is a necessity because it makes it easier for students and lecturers to carry out learning that is not limited to space and time (Sadikin, Saudagar, and Muslim, 2018). This is supported by the use of the internet in learning which will enable students to obtain the latest knowledge and information (RUsman, 2014). A paradigm shift in learning in the 21 st century demands a change in thinking, namely that students can have high order thinking skills (HOTS) critical thinking skills, find solutions, be creative, innovate, communicate, collaborate, and have information and media skills (Sutrisno, 2011; Rizkamariana \& Wulan, 2019).

In vocational education such as polytechnic education, skills are highly demanded to be better prepared to face the world of work. At present, especially in the Marketing Management course at Malang State Polytechnic, there are still many lecturers who use the learning method with the lecture method in the classroom so that it can be categorized as Teacher-Centered Learning (TCL). This situation becomes a problem because the ability of students in general in the field of skills is lacking and there is still low interest and readiness of students in learning because with the lecture method students tend to be less active and more listening. For this reason, to improve student motivation and ability in learning, it is necessary to change the learning model, one of which is to use the blended learning model.

In the application of the blended learning model, face-to-face learning is combined with e-learning. Blended learning is a new concept in learning where material delivery can be done in class and on-line (Husamah, 2014). The blended learning method which is accompanied by the enrichment of several kinds of learning methods that require active students and critical thinking will turn it into student-centered learning or often known as Student-Centered Learning (SCL). The SCL learning method that can be integrated into the blended learning model includes problem-based learning accompanied by practice rehearsal pairs. The learning with a problem-based learning approach (problem-based learning) has been widely carried out in vocational education environments in various universities (Badeau, 2010). Apart from aiming at improving the professionalism of graduates, it is also a form of responsiveness to the emergence of the 21 st-century learning paradigm. In addition, the practice rehearsal pairs method is one of the methods derived from cooperative learning (active learning) which invites students to learn actively in finding main ideas from the learning material, solving problems, or applying what they have just learned (Supriono, 2013).

Previous research found that the application of blended learning was able to positively influence learning outcomes (Muthoharoh, 2017). In addition, Usman (2018) found that the blended learning method was able to improve the quality and quality of learning and was able to increase the motivation, interest and learning outcomes of students. There was also a fairly high difference between conventional learning and blended-based learning and the application of blended learning could improve student learning outcomes as well as satisfaction and efficiency (Destiana, et.al., 2019). Likewise, research conducted by Prawoto and Pramulia 
(2019) found that the application of blended learning could stimulate and foster learning motivation for students and can improve learning outcomes because of the tendency of students to be more active, innovative, creative, and enthusiastic in independent learning.

Studies have repeatedly shown that students, regardless of age, are motivated and able to learn new technologically based tasks (Bruder, 2014). Moreover, students can significantly increase their abilities to work with new technology with proper training (Bruder, 2014). Older students can optimize their results through extended practice (Bruder, 2014). Younger students will adapt more quickly to technological issues and learn to master the technology at an advanced rate (Bruder, 2014).

The new generation being so interrelated with technology, and it becomes nearly a must to use technology in classes. Dudeney and Hockly (2012) Refers to today's kids as digital natives who grow up using technology and the parents as digital immigrants who have come late to the world of technology.

Scaffolding is widely considered an essential component of effective instruction; therefore, the scaffolding strategy has been wildly employed to include several tools such as multimedia and hypermedia software to provide learners with supports (Kim \& Hannafin, 2011). Most studies applying scaffolding theory provided static scaffolds in their learning contexts without considering students' changes during the learning process. However, learning styles may be influenced by students' experiences, so they are not unchanged traits that can be measured through explicit questionnaires once and ignored until the end of the implementation.

Individual differences among students have significant effects on their learning outcomes (Rukanuddin, Hafiz, \& Asfia, 2016). Previous studies examined these effects and indicated that providing the same learning materials and delivering the same instructional conditions to all students may lead to a reduction in learning performance without considering their different background characteristics, prior knowledge, experiences, and learning aptitudes (Smith-Jentsch et al., 1996; Ford \& Chen, 2000). For ensuring effective learning for all students, adapting teaching strategies and content to meet individual student needs has long been regarded as a central and persistent issue in education.

The term adaptive learning refers to a method of online instruction that involves providing personalized learning experiences resulting from a data-driven approach to curriculum design. This method builds on customized learning paths derived from algorithms, course analytics, assessment data, and feedback from students and can be used both to provide remediation and to help learners achieve mastery of content (Educause, 2017).

Therefore, Adaptive Learning Method (ALM) is the solution for rural students as ALM adapt to learning style, students' needs, students' available learning tool-tech, and authentic content.

This article presents the report of a study conducted with the focus of identifying the effectiveness of a problem-based learning as implemented in a blended system, combining offline and online learning system. 


\section{$3^{\text {rd }}$ International conference on Advanced Research in Education, Teaching \& Learning}

\section{Methods}

This quasi-experimental research was aimed to explore the effectiveness of a problembased learning presented in a blended system. Students' responses toward the implementation of the program was also explored. Respondents were 160 students taking Marketing Management course of Accounting Department of the State Polytechnic of Malang; samples were selected through purposive random sampling. Respondents were equally divided into control and experiment groups with 80 students in each group. The data were collected through a pre-test, a post-test, and a questionnaire.

At the beginning of the study, both the control and experiment groups were asked to have pre-test. Then, the control group went through the learning of Marketing Management course using conventional strategy, the teaching strategy previously implemented in the class. The class did not apply problem-based learning, and the class was held face-to-face. The experiment group went through the learning implementing problem-based learning that was presented in a blended learning system, a combination of face-to-face and online class. After the treatments, both groups did the post-test. Then, questionnaire was also distributed to the experiment group. The questionnaire was aimed to identify students' responses on the implementation of the problem-based learning as presented in a blended learning system.

\section{Findings and Discussion}

Descriptive statistics of the initial ability (pre-test) and the ability after being given treatment (post-test) as well as the progress gained of both control and experiment groups is presented in Table 1. As seen in the table, the pre-test scores of both groups were not far different; the control group's average score of pre-test was 69.6 while the experiment group's score was 71.7. However, the results of the post-tests of the experiment group (78.41) was higher than the control group's scores (72.33). The progress gained by the experiment group (6.71) was also higher than the that gained by the control group (2.72).

Table 1. Descriptive statistics of control and experiment groups for the pre-test, post-test, and progress gained

\begin{tabular}{lll|r|r|r} 
& & Mean & N & Std. Deviation & Std. Error Mean \\
\hline \multirow{2}{*}{ Pair 1 } & Pre-test of Control Group & 69.6000 & 80 & 7.16638 & .80123 \\
\cline { 2 - 6 } & Pre-test of Experiment Group & 71.7000 & 80 & 7.46197 & .83427 \\
\hline \multirow{2}{*}{ Pair 2 } & Post-test of Control Group & 72.3250 & 80 & 7.05274 & .78852 \\
\cline { 2 - 6 } & Post-test of Experiment Group & 78.4125 & 80 & 7.53506 & .84244 \\
\hline \multirow{2}{*}{ Pair 3 } & Progress Gained by Control Group & 2.7250 & 80 & 5.82655 & .65143 \\
\cline { 2 - 6 } & Progress Gained by Experiment Group & 6.7125 & 80 & 6.63553 & .74187 \\
\hline
\end{tabular}

Correlational analysis was also done to correlate the data of both control and experiment groups. Table 2 presents the results of the statistical analysis of paired samples correlation, analysing the correlation between the control and experiments groups. As seen in Table 2, there was no significant correlation between the control group and experiment group. Moreover, the post-test results of the control group were negatively correlated to the scores of the experiment group. the same was also true with the progress gained by the two groups; the progress scores of the control group were negatively correlated that of the experiment group. 
Table 2. The results of t test for the comparison of outcomes for control and experiment groups

Paired Samples Correlations

\begin{tabular}{lll|r|r} 
& & $\mathrm{N}$ & Correlation & \multicolumn{1}{c}{ Sig. } \\
\hline Pair 1 & Pre-test control \& experiment groups & 80 & .020 & .864 \\
\hline Pair 2 & Post-test control \& experiment groups & 80 & -.139 & .218 \\
\hline Pair 3 & Progress gained by control \& experiment groups & 80 & -.089 & .435 \\
\hline
\end{tabular}

Furthermore, to find out the significant differences in the values of post-test and progress gained by both groups, a statistical testing using the paired t-test (paired-sample t-test) was done. The significant levels accepted was decided to be below 0.05 .

As presented in Table 3, it can be seen that the paired t- test results for the difference between the pre-test scores of the control group and experiment group shows a t-value of 1.833 which was significant at 0.071 . this means that there was no significant difference between the scores of the control group and that of the experiment group. this may mean that both groups started the class with equal knowledge and skills of marketing management course.

Statistical analysis result of the post-tests of both control and experiment groups show a tvalue of -4.943 with the significant level of 0.000 . This shows that there was significant difference in the results of post-test, with the experiment group attained higher scores than the control group did.

Furthermore, progress attained by both control and experiment groups were also statistically calculated. Results of the analysis show t-value of -3.872 , conveying that there was a significant difference in the progress attained by the two groups with the significant level of 0.000 . This underlines the fact that the experiment group significantly gained higher progress than the control group did.

Table 3. The results of t test for the comparison of outcomes for control and experiment groups

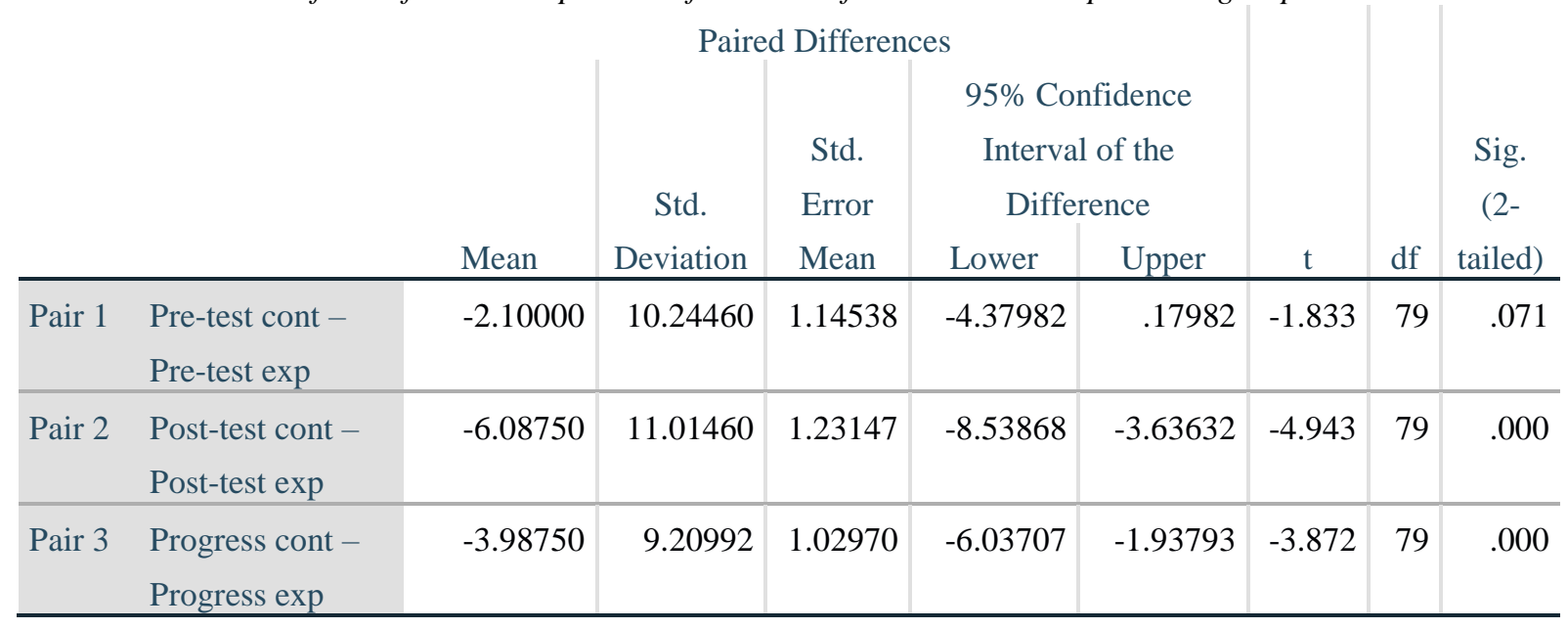

The hypothesis tested in this study was whether progress attained by the experiment group learning the materials through problem-based presented in blended learning was significantly higher than the progress gained by the control group who learned the materials through conventional method. With the above-stated data, it can be concluded that the Ho was rejected and the working hypothesis was accepted. 
Thus, it can be concluded that in general, the achievement scores of marketing management of students who learned through problem-based learning presented in a blended system were higher than that of the control group with conventional learning strategies. The results of this study support previous related research (for example Collis \& Moonen, 2001; Osguthorpe \& Graham, 2003; Twigg, 2003; Young, 2002) which claimed that a class with the application of blended learning was more effective than a class that applied a face-to-face approach only. This was also in accordance with Thorne's idea (2003) that blended learning was better than conventional learning because blended learning integrates innovation and technological advances using online learning and media.

The results of this study are also in line with research conducted by Dziuban et al. (2004) who found that blended learning has the potential to improve learning outcomes. This situation is partly because blended learning combines several aspects such as web-based instruction, video streaming, synchronous and asynchronous communication, and face-to-face learning (Ahmed, et.al., 2008; Salata, 2017).

Further data were gathered regarding students' responses to the implementation of problem-based learning as presented in a blended system. Respondents' responses to the distributed questionnaire are as presented in Table 4.

Table 4. Students' responses toward the implementation of problem-based learning presented in blended system

\begin{tabular}{llc}
\hline No & \multicolumn{1}{c}{ Statements } & $\begin{array}{c}\text { Responses } \\
\text { (Scale 1-5) }\end{array}$ \\
\hline 1 & $\begin{array}{l}\text { I feel more motivated to learn materials presented in problem-based learning than those } \\
\text { presented in lectures only. }\end{array}$ & 3.81 \\
\hline 2 & I would feel more easily bored when the learning materials are presented in lectures only. & 3.74 \\
\hline 3 & $\begin{array}{l}\text { I can comprehend and understand the materials better when presented in problem-based } \\
\text { learning. }\end{array}$ & 4.08 \\
\hline 4 & $\begin{array}{l}\text { Problem-based learning can improve my ability to think critically and creatively } \\
\text { I feel more motivated to learn from the real cases as found in real business. }\end{array}$ & 3.11 \\
\hline 6 & $\begin{array}{l}\text { The learning materials delivered using problem-based learning and presented in blended } \\
\text { system are challenging and interesting. }\end{array}$ & 3.88 \\
\hline 7 & $\begin{array}{l}\text { I believe that the implementation of blended learning system would improve my } \\
\text { achievement scores higher than the offline face-to-face learning system. }\end{array}$ & 3.99 \\
\hline 8 & $\begin{array}{l}\text { I can easily access the learning materials provided online (via mobile phone or computer) } \\
\text { as implemented in blended learning system. }\end{array}$ & 3.90 \\
\hline & $\quad$ Average all & 3.92 \\
\hline
\end{tabular}

Note: 1 - strongly disagree to 5 - strongly agree

As seen in the table, from all the 8 questions, students voiced positive responses regarding the implementation of problem-based learning presented in a blended system. Within the range from 1 to 5 , students stated that they felt motivated to learn materials offered in a problem-based learning. The responses value was 3.81. Problem-based learning presented in a blended system also made students felt less bored. Students could better comprehend and understand the materials which were presented in a problem-based learning. This strategy also 


\section{AREIL}

\section{$3^{\text {rd }}$ International conference on Advanced Research in Education, Teaching \& Learning}

made students think more critically and creatively. Learning materials as found in real business made students more motivated to learn more. Furthermore, students found the learning materials more interesting and challenging (in a positive way) when presented through blended learning system than through face-to-face lectures only. Students also stated that they could easily access the materials through computer or mobile phone. Finally, students believed that the implementation of problem-based learning as presented in a blended system would improve their learning achievement better than the materials presented in a conventional learning method and face-to-face lectures.

The implementation of the learning strategy in the current study impacted on the improved motivation and interest to further learn the materials. These affective factors have been known as very influential in the effective attainment of learning objectives. The results of this study are supported by Lakonawa et al. (2014) who prove that motivation will encourage and guide students to be more encouraged to learn so that with high motivation, students will be able to maintain their enthusiasm for learning.

The effectiveness of the strategy of putting problem-based learning into a blended learning system as proven in the current study can be upgraded its implementation into the implementation of adaptive learning. Upgrading the strategy into adaptive learning method can be done by individualizing the problem-based learning materials and putting them into a computerized system. Following the pillars of adaptive learning as stated by Educause (2017), therefore, enriching the learning materials need to be done, providing enforcement materials to accommodate fast learners and remedial materials to facilitate slow learners. Thus, adaptive learning which is believed to be potentially effective in the coming years can be realized.

\section{CONCLUSIONS}

Based on the results of the analysis and testing of research hypotheses, this study can be concluded that there is a significant difference in the learning outcomes of Marketing Management between groups of students who learn materials presented in a problem-based learning presented in a blended system and groups of students using conventional learning strategies. The effectiveness of the strategy in improving students' learning achievement may also be influenced by students' improved affective factors such as improved interest to learn, increased motivation to study.

The effectiveness of problem-based learning as presented in a blended learning system supports the potential implementation of adaptive learning in the future by embedding individualized learning method into the strategy.

\section{Acknowledgment}

This paper is an output of a collaborative research between State Polytechnic of Malang, Indonesia, and University College Yayasan Pahang, Malaysia conducted in the year of 2020. 


\section{References}

Ahmed, A.H., Nabeel Al-Huwail, and Salah Al-Sharhan. (2008). Blended e-learning design: Discussion of cultural issues. Journal of Cyber Society and Education. 17-32.

Badeau, K.A. (2010). Problem-Based Learning an Educational Method for Nurses in Clinical Practice. Journal for Nurses in Staff Development. 26 (6).

Bruder, C., Blessing, L., \& Wandke, H. (2014). Adaptive training interfaces for lessexperienced, elderly users of electronic devices. Behaviour \& Information Technology, 33(1), 4-15. doi:10.1080/0144929X.2013.833649

Chen, W. K. (1993). Linear Networks and Systems. Belmont, CA: Wadsworth, pp. 123-135.

Collis, B. \& Moonen, J. (2001). Flexible Learning in A Digital World: Experiences and Expectations. London: Kogan-Page.

Destiana, I.D., W. E. Rahayu, N. Mukminah, and O. Yudianto. (2019). Penerapan Model Blended Learning untuk Meningkatkan Hasil Belajar Mahasiswa Agroindustri Politeknik Negeri Subang. EDUFORTECH. 4 (2), pp. 71-80.

Dudeney, G. and Hockly, N. (2012). How to teach English with Technology, Edinburgh Gate: Pearson Education Limited.

Dziuban, C.D., Joel L. Hartman, and Patsy D. Moskal. (2004). Blended Learning. Research Bulletin. Volume 2004, Issue 7, March 30.

Educause. (2017). 7 things you should know about adaptive learning. Retrieved from https://library.educause.edu/ /media/files/library/2017/1/eli7140.pdf

Ford, N., \& Chen, S. Y. (2000). Individual differences, hypermedia navigation, and learning: an empirical study. Journal of Educational Multimedia and Hypermedia, 9(4), 281-311.

Husamah. (2014). Pembelajaran Bauran (Blended Learning). Jakarta: Prestasi Pustaka Jaya.

Kim, M.C., \& Hannafin, M.J. (2011). Scaffolding problem solving in technology-enhanced learning environments (TELEs): Bridging research and theory with practice, Computers \& Education, 56(2), 403-417.

Lakonawa, P., A. Benawa, and M. M. Bali. (2014). Pengaruh Kemampuan Dosen dalam Mengelola Kelas dan Model Pembelajaran Terhadap Motivasi Belajar Mahasiswa Binus University. HUMANIORA. 5 (1), pp. 316-323.

Muthoharoh, N.B. (2017). Pengaruh Penggunaan Teknologi Pembelajaran Blended Learning Terhadap Hasil Belajar Menulis Teks Fungsional Pendek Bahasa Inggris. DEIKSIS. 9 (03). pp. 360-373.

Osguthorpe, R. \& R. Graham. (2003). Blended Learning Environments: Definitions and Directions. The Quarterly Review of Distance Education, 4(3), pp. 227-234.

Pannen, P. (2018). Mempersiapkan SDM Indonesia di Era Industri 4.0. Jakarta: Kemenristekdikti.

Prawoto, E.C. and Pramulia. (2019). Pembelajaran Sastra Berbasis Blended Learning. Efektor. 6 (1), pp. 37 - 42. 


\section{ARELL}

\section{$3^{\text {rd }}$ International conference on Advanced Research in Education, Teaching \& Learning}

Rizkamariana, F., S. Diana, and A. R. Wulan. (2019). Penerapan Project Based Learning untuk Melatih Kemampuan Literasi Tumbuhan Abad 21 pada Siswa SMA. Assimilation: Indonesian. Journal of Biology Education. 2(1) pp. 19-23.

Rukanuddin, M., Hafiz, K. D., \& Asfia, R. (2016). Knowledge of Individual Differences of the Learners of Second Language Enriches Second Language Teaching. Journal of Literature, Languages and Linguistics, 19, 11-15.

Rusman. (2014). Model-model Pembelajaran (Mengembangkan Profesionalisme Guru. Jakarta: Raja Grafindo Persada.

Sadikin, A. and N. Hakim. (2019). Pengembangan Media E-Learning Interaktif Dalam Menyongsong Revolusi Industri 4.0 Pada Materi Ekosistem Untuk Siswa SMA. Jurnal Ilmiah Pendidikan Biologi. 5 (2). September, pp. 131-138.

Sadikin, A., F. Saudagar, and F. Muslim. (2018). Development of the Biology Textbook of Process Evaluation and Learning Outcome for Students in Biology Education, University of Jambi. BIODIK. 4(2), pp.83-94.

Salata, T.L. (2017). Increasing a Sense of Place Using Blended Online and on Site Learning. Journal of Sustainability Education. Vol. 12 (February).

Smith-Jentsch, K. A., Jentsch, F. G., Payne, S. C., \& Salas, E. (1996). Can pretraining experiences explain individual differences in learning? Journal of Applied Psychology, 81(1), 110.

Suprijono, A. (2013). Cooperative Learning Teori \& Aplikasi PAIKEM. Yogyakarta: Pustaka Belajar Celeban Timur.

Sutrisno. (2011). Pengantar Pembelajaran Inovatif Berbasis Teknologi Informasi dan Komunikasi. Jakarta: Gaung Persada Press.

Thorne, K. (2003). Blended learning: How to integrate online and traditional learning. London: Kogan Page Publishers.

Tjandrawinata, R.R. (2016). Industri 4.0: Revolusi industri abad ini dan pengaruhnya pada bidang kesehatan dan bioteknologi. Jurnal Medicinus. 29 (1). April.

Twigg, C. (2003). Improving Learning and Reducing Costs: New Models for Online Learning. Educause Review. 38(5), pp. 28-38.

Usman. (2018). Komunikasi Pendidikan Berbasis Blended Learning Dalam Membentuk Kemandirian Belajar. Jurnalisa. 04 (1), pp. 136-150.

Warsita, B. (2008). Teknologi Pembelajaran Landasan dan Aplikasinya. Jakarta: Rineka Cipta.

Young, J.R. (2002). Hybrid Teaching Seeks to End the Divide Between Traditional and Online Instruction. The Chronicle of Higher Education. 48 (28), A33-A34. 